\title{
Determinants of Value Addition in the Seafood Industry in Developing Countries: An Analysis of the Kenyan Context
}

\author{
Ms. Fridah Simba Theuri; Dr. Fred Mugambi Mwirigi and Prof. G. Namusonge \\ Jomo Kenyatta University of Agriculture and Technology (JKUAT)-Kenya.
}

\begin{abstract}
The seafood sector contributes significantly to many coastal economies in generating income, employment, and foreign exchange earnings to the fishing communities, fish traders, fish processors and fish farmers. The sector supports about 80,000 Kenyans directly and about 800,000 indirectly. The sector is one of the key contributors to food security and poverty alleviation in many developing nations. Currently, most fish is handled, processed, transported and stored without proper equipment, which means low hygienic standards, unhealthy food products that cannot easily access the outside market. The study identified, strategic planning activities and processes, technological competitiveness, level of market competition and corporate policies as key determinants. Information gathered and the recommendations thereof will help to create a more complete and efficient chain.
\end{abstract}

Key words: value addition, sea food, value chain

\section{The Global Perspective}

\section{Background}

The world seafood industry plays a significant role in the economic and social wellbeing of nations, as well as in the feeding of a significant part of the world's population. Fishing and fish farming has emerged as one of the major food processing occupations of mankind. In ancient times, economically and socially backward people were employed in this profession. The advent of modern mechanized fishing vessels has brought vast changes in the attitude of the public fishing and seafood processing. From low income and socially backward communities the profession has shifted to the hands of industrialists and technologists (Visvanathanm et al, 2006).

Today fishing and processing activities provide employment to millions of people around the world. The world's population is expected to increase by $36 \%$ in the years 2000 to 2030 , to 8.3 billion. It is also expected that the estimated total seafood demand will be 183 million tons by 2030, but the estimated supply will be only 150 to 160 million tones. Thus, there is a sizable gap between demand and supply. However, global capture fisheries will be able to provide only 80-100 million tons of fish annually on a sustainable basis (Bastien, 2003)

The global seafood market is estimated at US\$ 100 billion per annum. Also, the world demand for seafood increases by $3 \%$ each year. The world largest seafood consumption in the world is by Japan, followed by European Union with the top five consumed species being salmon, shrimp, tilapia, cat fish and crab (FAO, 2006).

\section{The Kenyan Perspective}

Agriculture remains the engine of Kenya's economic growth, accounting for 27 percent of real GDP, 60 percent of the country's total export earnings, and 45 percent of government revenue. Some 75 percent of Kenyans are employed in the agricultural sector .Agriculture also provides employment and livelihood to a large percentage of the population with an estimated $75 \%$ of the population depending on the sector either directly or indirectly (RoK, 2012).Kenya's fisheries resources are important sources of food, employment and foreign exchange. Kenya's fishing communities have relied on fish as a rich source of protein, In fact, in some communities' fish has additional cultural values. There are at least 80,000 people working as fishers and fish farmers. The sector also provides livelihoods for about 2.3 million Kenyans involved mainly in fish processing and trade (RoK, 2008).

Kenya has a large agro-processing industry, reflecting the importance of the agricultural sector in the Kenyan economy. The majority of the pioneer industries during the colonial period were agro-based. A wide range of agro-industries still exist today, ranging from processing staple foods and fruits, to fish processing for both domestic and foreign markets. Food processing is thus one of the key activities in Kenya's agro-processing Industry (Export Processing Zone, 2005)

Kenya has a long history of fishing with the Luo, Luhyia, and Abasuba ethnic groups having been active fishermen for more than five centuries. Until 20 years ago nearly all fish caught in Kenyan waters was consumed locally. Kenya started to export fish in the early 1980s, when fish processing factories were 
established around Lake Victoria. Thus over the past 20 years, the fisheries sub-sector has gradually evolved from a domestic consumption oriented industry to an export oriented industry with value added processing being applied.

Kenya has a marine coastline of 536 Kilometers, In spite of this, Lake Victoria continues to dominate Kenya's fishing output source. The lake currently accounts for over $90 \%$ of the tones of fish caught while marine fishing accounts for only $4 \%$ of the total output. Kenya claims $6 \%$ of Lake Victoria's total surface area, with $43 \%$ being owned by Uganda and $51 \%$ by Tanzania. Lake wide fish production is estimated at between 400 - 500 metric tons with Tanzania landing 40\%, Kenya 35\% and Uganda 25\%. The landed value of this catch is between USD 300 - 400 million annually (Export Processing Zone, 2005)

The quantity of fish landed rose by 8.2 percent from 133600 in 2009 to 144505 in 2010. However, earnings from fishing, largely from the country's freshwater bodies rose by 36.2 percent from KSh13 billion in 2009 to KSh 17.7 billion in 2010. The jump in earnings was both, because of higher catches and better domestic and export prices (RoK 2011). Lake Victoria accounted for the largest quantity (78.7 percent) and highest value of fish landed by freshwater body. Admittedly, Vision 2030 does not specifically identify fishing as one of the priority sectors. However, it is an important subsector because it is a major source of livelihood for communities which live on the shores of Lake Victoria, Lake Turkana and Lake Naivasha, and those who live near the Tana River and Indian Ocean.

Fishing in Kenya is mostly carried out by artisanal fishermen operating small fishing boats in inland lakes and marine waters. Some fish is sold fresh while a significant proportion is processed for later consumption. Artisanal Fish Processors (AFPs) prepare dried and smoked fish mostly for local market, while Industrial Fish Processors (IFPs) freeze or chill fish for export and to a lesser extent, for consumption in Kenya's urban areas. IFPs' have become the industry's driving force. They collect fish from the beaches using refrigerated trucks, buying through intermediary medium and large-scale traders and process them for export.

The fisheries sub-sector is expected to continue to grow and expand, taking advantage of the lifting of EU ban to increase their exports to Europe and the discovery of new emerging markets for Kenyan fish products such as Israel and Dubai. Enhancement of quality standards in fish processing is also expected to stir growth in the sub-sector by increasing demand for Kenyan fish. The decision by the EU in December 2003 to upgrade Kenya from category II to I of the countries exporting food to the Europe market is also expected to further improve the fishing industry in Kenya. This will also ensure that fish destined to both local and export markets are handled in the most appropriate manner minimizing post fishing losses and relieving stress on the capture fishery.

\section{The Industry Structure}

There are 17 industrial fish processing companies in Kenya all of which are export oriented and can be classified as either land based establishments or water-based freezer vessels. These companies mainly produce frozen and chilled fish for export to European and other non-European markets. These companies deal in different fish species including Nile Perch, prawns, lobsters, octopus, cuttlefish and squids.

Among the newest industrial fish processing companies that have been established include; Fish Processors (2000) Ltd, Samaki (2000) Ltd, Banner Distributors Ltd and Crustaceans Processors. The 17 industrial fish processors in Kenya have an installed capacity of 437 Metric tons per day of which only 213.4 metric tons per day is utilized. The sector is regulated and controlled by the Fisheries Department, which falls under the Ministry of Livestock \& Fisheries. Setting up fish processing facilities in Kisumu and at the coast is in line with the Vision 2030 targets to contribute to the growth of the manufacturing sector, with positive outcomes for Vision 2030. This is because it will increase the value added component of the sector and also stimulate the growth of off shore fishing, which is largely untapped.

\section{Purpose Of The Paper}

The purpose of this paper is to highlight and analyze the key determinants of value addition in the sea food industry in developing countries with specific reference to the Kenyan context. Information gathered and the recommendations thereof will help to create a more complete and efficient sub -chain and, therefore, optimize the economic as well as social benefits of the fishing industry to the country. It will further, assess the key value chain activities that characterize the sea food industry in Kenya with the view of establishing their completeness and efficiency.

\section{The Need To Enhance Sea Food Value Chains}

Kenya's fisheries sector plays an important role in the national economy. For instance, the sub-sector total earnings from fish landed rose from KSh 11.5 billion in 2008 to KSh 12.0 billion in 2009 attributed to increased fish landings and favorable domestic and export market prices (FAO, 2012). The value of freshwater fish increased from KSh 10.72 billion in 2008 to KSh 11.2 billion in 2009, accounting for $93.5 \%$ of the total 
revenue generated from the fisheries sub-sector in 2009 (RoK, 2010). This figure could have been higher if value addition at the various stages of the supply chain are considered and post harvest losses minimized.

Additional statistics indicate that the sector contributes significantly to many coastal economies and developing countries in generating income, employment, and foreign exchange earnings to the fishing communities, fish traders, fish processors and fish farmers. The sector supports about 80,000 Kenyans directly and about 800,000 indirectly (RoK, 2008). In addition, the fishery sector is one of the key contributors to food security and poverty alleviation in many developing nations (FAO, 2012). The developing world is also more dependent on fish as their source of protein, having a 20.0 percentage contribution of fish to total animal proteins, compared with the developed world's 12.3 per cent (Laureti, 1999). It is, therefore, clear that expanding the fishery sector has contributed to economic growth in the developing world.

According to the Vision 2030, (RoK, 2010), the economic pillar focuses on moving the economy up the value chain. One of the ways of achieving this is through the agriculture sector that requires a strong focus on increasing market access through value addition and by processing, packaging and branding the bulk of agricultural produce. This entails proactively exporting value- added goods to regional and global markets.

However, it is evident that a lot more growth can be achieved in this sector. For instance statistics show a disconnect between value addition and production of fish. The production of fish in the year 2010 was 158,000 tones, whereas the fish traded was 78,000 tones (FAO, 2012. This is indicative of the amount of wastage that is occurring in the value chain of fish where a lot of fish is sold unprocessed. For instance in spite of the fact that Kenya produced 158,000 tons of fish as indicated above during period 2010, there only exist one Tuna factory that produces cooked frozen Tuna loins, its note worthy that even after this process the tuna has to be taken to $\mathrm{EU}$ for further processing. This is possible if key players in the industry can identify deficient value addition points in the sea food supply chain and step up value addition. Most sea food in Kenya is handled, processed, transported and stored without proper equipment and through fairly unhygienic and un standardized processes, which makes it very difficult for Kenya's sea food products to easily access the outside market. Even in the face of these challenges, very little in the way of enhancing the entire fish processing and marketing value chain has happened in the last decade.

The Kenyan seafood industry presents a complexity of interwoven value chains which cut across fresh and processed fish, industrial and artisanal processing, domestic and export markets and food and feed products. The sea food sector would have probably grown further if value addition at the various stages of the supply chain are considered and post harvest losses minimized. The biggest challenge, therefore, is how to enhance the sea food value chain by adding value at various points in order to make the industry and its products competitive both within and outside the Kenyan market.

\section{Traditional Fish Processing Methods}

\section{Fish Processing In Developing Countries}

In many African countries, the most popular traditional fish preservation methods are by smoke-drying, hot smoking, sun drying and dry salting. This is also reflected in the bulk of the fish sold in most markets.

Fish smoking is relevant in the artisanal fisheries in that it prolongs the shelf life of the fish, enhances flavour and increases utilization of the fish, reduces waste when catches are good, and increases protein availability to people (Jallow, 1995). Traditionally, the method uses much labour, with women complaining of smoke in their eyes. Lots of firewood is used which raise environmental concerns. Poor quality, burnt and breakable fish products with low market value are produced in the end.

The use of sun dried fish is also common in several other areas of the coast. During glut, the processors in some of these areas however lay the fish on the ground or on sand occasionally covered with fishing nets or on rocks to dry (Per. Com. Fisheries Dept.). The disadvantage of this method is that the slow drying process makes it unhygienic and also contributes to partial destruction of proteins and lipid oxidation. If drying is near homes, the fish has to be brought inside every time it rains and each evening to avoid dew and moulds. Dust Contamination, insect infestation, and exposure to harmful human and animal handling are the other disadvantages of natural outdoor drying. These result in very low quality fish with limited market circulation hence low income.

\section{Fish Supply Chain in Kenya}

In the fisheries industry, one may describe the value chain as in the figure below consisting of eight links as in this case. For the purpose of this study, we will focus on the processing link and this is where majority of the IFPs are found. 


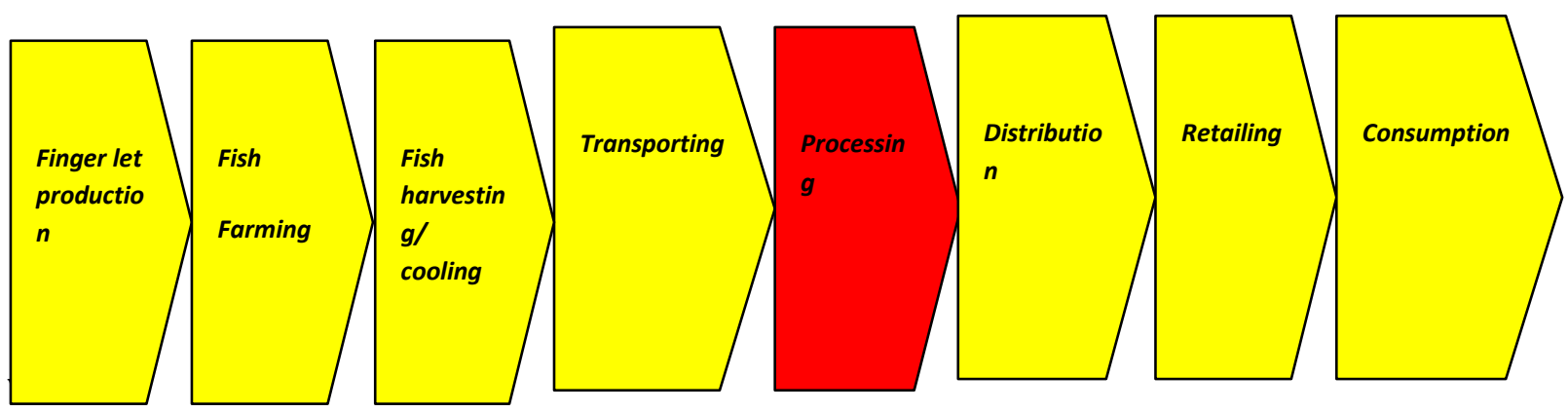

Fig. 1: A simple value chain in fisheries.

Source: Simba, 2013

In most industries, it is rather unusual that a single company performs all activities from product design, production of components, and final assembly to delivery to the final user by itself. Most often, organizations are elements of a value system or supply chain. Hence, value chain analysis should cover the whole value system in which the organization operates. Within the whole value system, there is only a certain value of profit margin available. This is the difference of the final price the customer pays and the sum of all costs incurred with the production and delivery of the product/service such as raw material, energy among others (Recklies, 2001).

It depends on the structure of the value system, how this margin spreads across the suppliers, producers, distributors, customers, and other elements of the value system. Each member of the system will use its market position and negotiating power to get a higher proportion of this margin.
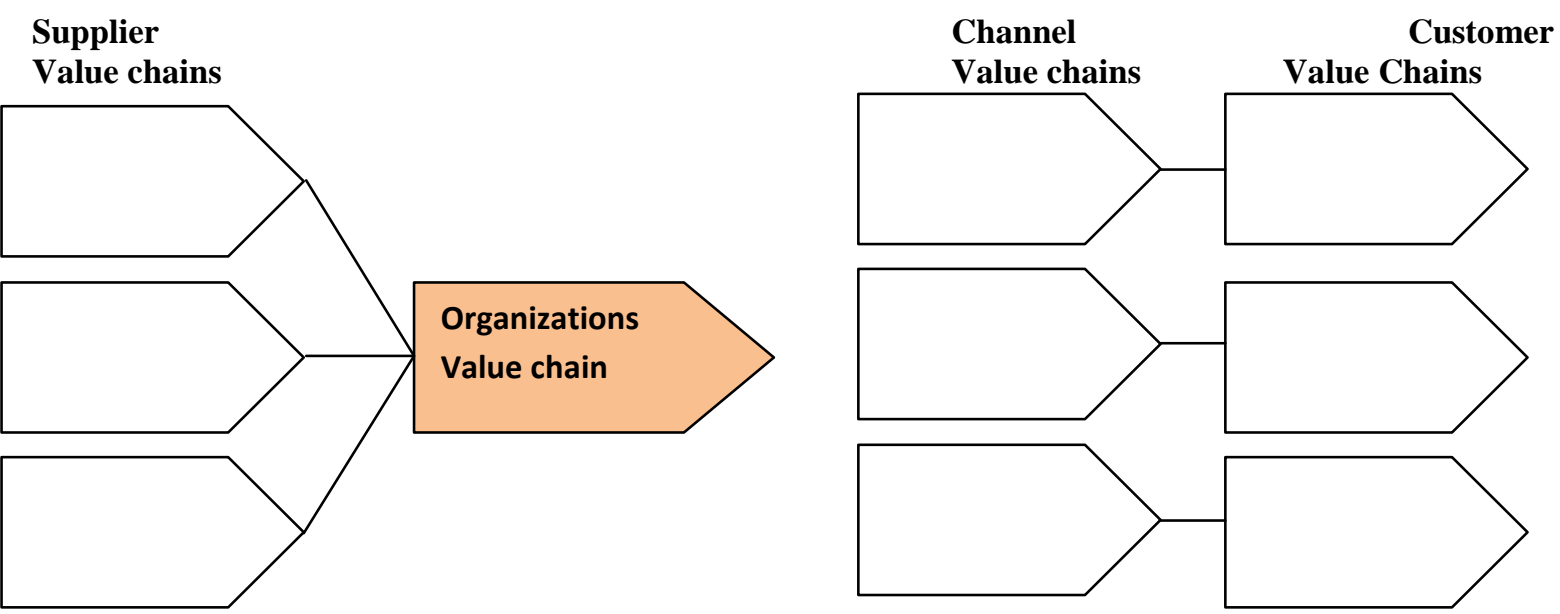

Figure 2: Value System Diagram

Source: Recklies, 2001

Nevertheless, members of a value system can cooperate to improve their efficiency and to reduce their costs in order to achieve a higher total margin to the benefit of all of them such as by reducing stocks in a Just-In-Time system. A typical value chain analysis can be performed in the following steps; step one, analysis of own value chain, where costs are related to every single activity. Step two, analysis of customers value chains, and for example how does our product fit into their value chain, the third step is identification of potential cost advantages in comparison with competitors and lastly identification of potential value added for the customer, how can our product add value to the customers value chain for example use lower costs or higher performance.

\section{Strategic Planning Activities}

\section{Determinants Of Value Addition}

Strategic management is a set of decisions and actions that result in the formulation and implementation of plans designed to achieve an organizations objectives via formulating the mission, developing the profile, assessing the external environment, analyzing the options, selecting the most appropriate option, developing the long-term objectives, implementing the strategic choices by means of budgeted resource allocations and evaluating the success of the strategic process as an input for future decision -making (Pearce \& Robinson,1999). 
Literature suggests that planning is a good management practice, and may be beneficial to business (Gibson et al 2002; Schwenk and Shrader, 1993). According to Berman, Gordon and Sussman (1997:14) "firms that plan produce better financial results than firms that do not plan". Bracker et al $(1986 ; 1988)$ found that firms that undertook strategic planning performed better financially. Lerner and Almor (2002) contend that planning lays the groundwork for developing the strategic capabilities needed for high performance. Strategic planning has been studied by various scholars including (Mintzberg, 1978, 1994; Brush and Bird, 1996; Bracker and Pearson, 1986; Braker, Keats and Pearson, 1988 ).

A strategic plan is built on a thorough analysis of the organization's existing structure, governance, staff, program or service mix, collaborations, and resources (financial, human, technical, and material). A welldeveloped strategic plan serves as a blueprint for making these changes because it describes the following; A vision for the future, Strengths and weaknesses of the organization, the nature of the changes contemplated for future sustainable growth and development, the sequence of these changes, those who are responsible for guiding change, the resources required, whether they currently exist within the organization or must be generated from external sources.

Strategic plans must also be systematically reviewed and revised so they remain topical, relevant, and "cutting edge." The whole organization must embrace the plan so that the "daily decisions are then made on the basis of this plan, which must be both practical - based upon your organization's mission - and flexible, to allow for rapid change."

There are some challenges which industrial fish processors face. There is lack of confidence in the data that drive fishery management decisions. Stakeholders are not as involved in the legislative process as they should and there should be different jurisdictions and regulations among the many fishery management organizations resulting into complexity and inconsistency. There is also need for increased transparency and clearer communications in fisheries management, the dynamics of the ecosystem and food web should be considered to a greater extent in fisheries management decisions. In addition, stakeholders should be adequately represented on the legislative bodies since pollution is negatively affecting the health of fish stocks.

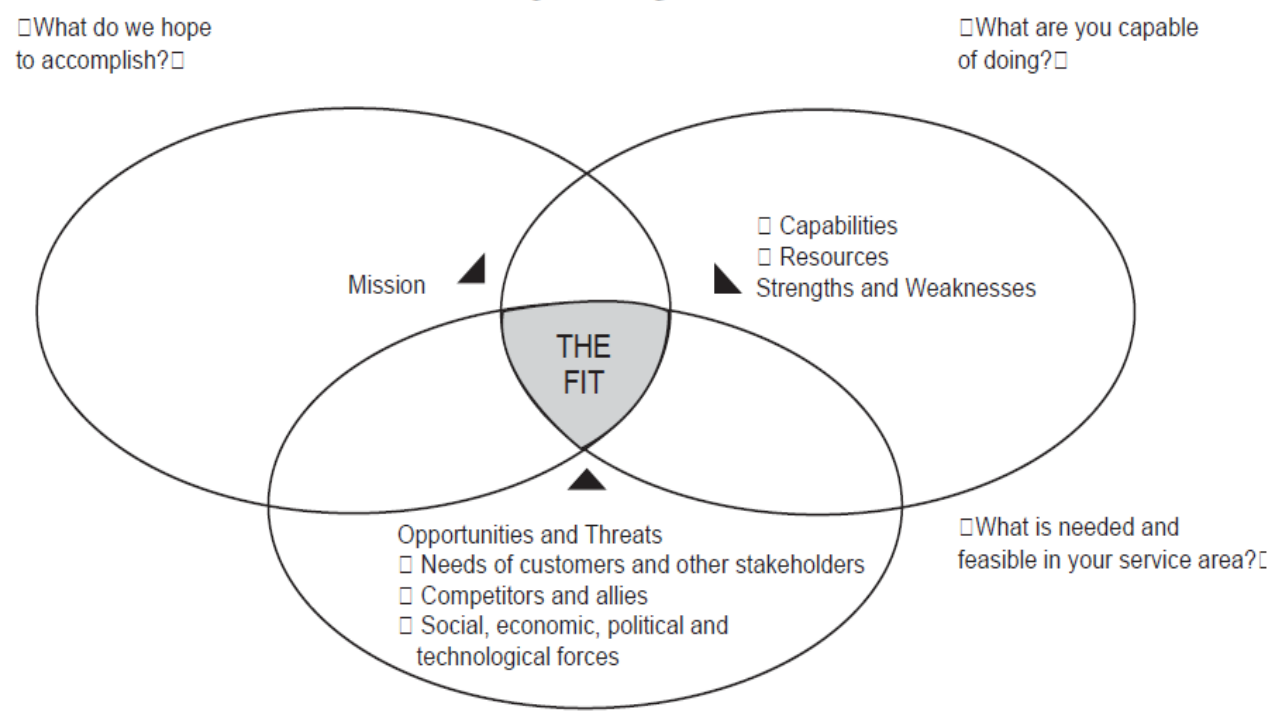

Figure 3: A model on some strategic aspects in organizations.

(Source: Barry \& Bryan (1997)

Technological Competitiveness of the Fish Processors

Technological Competitiveness can be defined as the ability to provide leading-edge technical capabilities, superior performance characteristics or reliability in a specific industry (ITCD, 2004).

According to the resource-based perspective, venture resources in the form of capabilities, assets, technology and skills provide competitive advantage and underpin the organization's performance (Barney 1991; Grant 1991; and Peteraf 1993). In other words, resource-based theory hinges on the resources and capabilities of the firm as an underlying factor of performance.

Currently most fish farmers and traders use, if anything self made basket with a liner in which the ice lasts for about six hours. These containers pose a challenge then since the farmers and traders have to clean them to meet the safety standards and regulations. Thus posing a risk in the sector since the technology being used is not competitive enough as compared to other international markets. 
The seafood processing industry needs new technologies to enhance quality, detect decomposition and extend product shelf life while adding minimal cost. New software will be needed to collect and manage data to allow a reliable prediction of remaining quality shelf life under controlled conditions.

The productivity and competitiveness of seafood processing depends not only on the sources and costs of raw materials, but also on the influence of other costly resources: energy, water, labor and waterfront space. Large amounts of energy are required for thermal operations such as refrigeration, cooking, and retorting. There are opportunities for conservation through energy audits and demonstrating new technologies at processing plants. Primary processors are located in the same coastal areas facing increased population density and tourism, all of which place high demands on limited supplies of fresh water. As just one example, it takes about 40 gallons of water to process one pound of Pacific shrimp. Improved management, education and technologytransfer programs could achieve significant reduction in water use, resulting in financial and environmental benefits. (Sea Grant, 2005).

IFP's should develop and demonstrate new technology to recover and use seafood by-products to increase profitability and decrease waste. For example, processes that produce fillets and portions generally leave a significant percentage of edible muscle tissue unused. Some success in recovering that protein could be achieved by adopting relevant technologies in place.

\section{Levels of Market Competition}

A company's position in a market channel is dependent on the following key decisions (adapted from Stern et al. 1996): one, which products or services will be delivered to which market. Secondly, what are the required intrinsic characteristics of the product or service and the required extrinsic characteristics of the production process and whether the company will adopt a single or multi-channel strategy? One company can deliver to more than one market (in terms of market requirements like quality level, delivery conditions, pricing). Lastly, the number of stages in the channel. For example a producer can deliver directly to customers further downstream the channel or through intermediary partners (such as traders, distributors or processors).

\section{The Export Market}

A wide variety of markets are linked to the capture fisheries value chain. The main markets are the export markets for industrially processed fresh and frozen Nile perch filets, and the domestic markets for fresh tilapia, artisanally processed fish (Nile perch, tilapia, omena1) and feed grade omena. These freshwater species markets handle $96 \%$ of Kenya's annual fish production of around 175,000 MT. In addition, a fifth set of markets are those related to Kenya's marine capture fisheries (shrimp, tuna, octopus, crab, etc.). Each of those markets is growing with supply generally lagging demand. (Ardjosoediro \& Neven, 2006).

The fish catch is sold directly on the beach to various traders. Industrial Fish Processors (IFP's) agents buy the Nile perch that meets the processors' criteria (e.g., size, freshness) who take the IFP's ice-laden trucks to the mainland beaches. Lower quality grade Nile perch, tilapia and omena are sold to a number of successive intermediaries along the supply chain: collecting traders, regional traders, wholesalers, and retailers. Most of the retailing takes place in urban open-air markets and through street vendors. Sales of domestic fish products in modern retail outlets such as supermarkets are limited. Grading and the use of ice are minimal in these domestic end-market channels, resulting in high spoilage levels.

Exports of fish are dominated by the export of Nile Perch to the EU. Europe accounts for more than $80 \%$ of East Africa's Nile perch market.

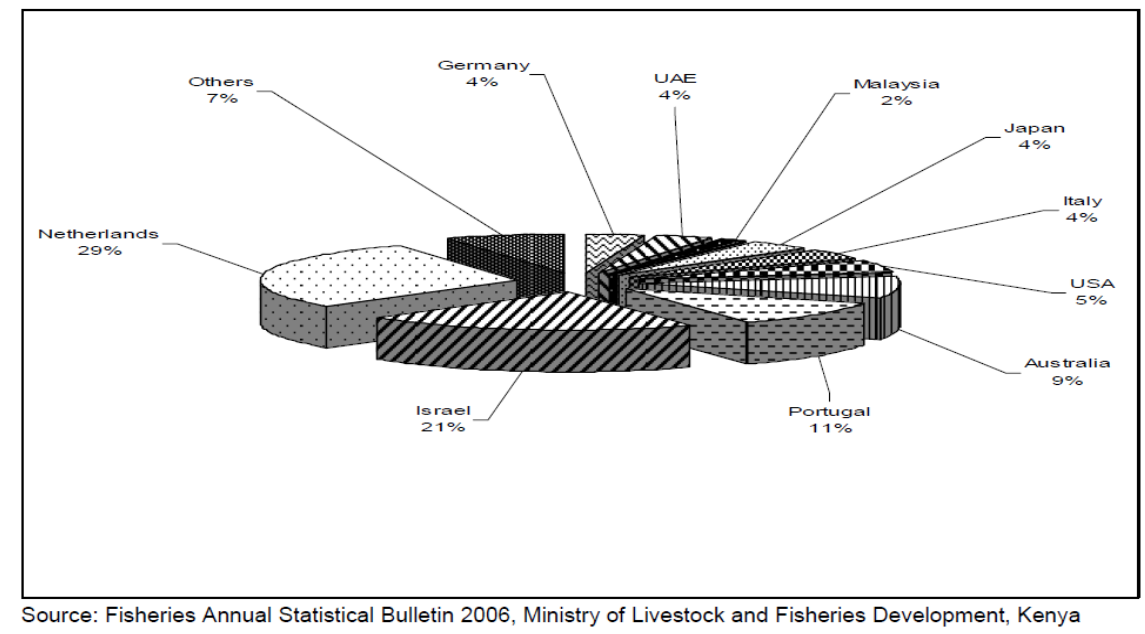

Figure 4: Exports of Nile Perch by Destinations, 2006 
In order to evaluate Kenya's competitiveness of its Nile perch export market share in the EU, it is important to compare and include the exports and landings from Uganda and Tanzania. The main product imported to the EU continues to be fresh fillet. This product accounts for $76 \%$ of the total quantity and $78 \%$ of the total value (Ardjosoediro \& Neven, 2006).

Table 2: Quantity Of Nile Perch Fillet Exports to the Eu By Main Exporting Countries (Mt)

\begin{tabular}{l|c|c|c|c|c|c|c|c|c|c}
\hline & 1997 & 1998 & 1999 & 2000 & 2001 & 2002 & 203 & 2004 & 2005 & 2006 \\
\hline Kenya & 7488 & 2447 & 1121 & 30 & 2747 & 3972 & 5086 & 6737 & 5184 & 4202 \\
\hline Tanzania & 9015 & 12506 & 4581 & 26857 & 23063 & 23119 & 26965 & 30813 & 23977 & 23564 \\
\hline Uganda & 8621 & 8894 & 2731 & 3451 & 14776 & 12213 & 13062 & 18539 & 23808 & 21179 \\
\hline Total & 25124 & 23846 & 8433 & 30338 & 40586 & 39303 & 45113 & 56089 & 52968 & 48945 \\
\hline
\end{tabular}

The Domestic Market

The main species that serve the domestic market are Tilapia and omena. The fisheries products consumed in Kenya consist of: Dried omena, Fresh, sun-dried, or smoked tilapia, by-products of Nile perch (artisanal processed). Domestic consumption of fish in Kenya has increased in the last years. Prices are as high as Ksh 140/US\$ 1.86 per kg and there is consumer awareness of the health benefits of eating fish as well.

Fish also provides raw material (fishmeal) for producing animal feeds for the growing livestock and dairy markets in Kenya. A fishmeal industry was established in Kenya in the mid 1990s. Fishmeal is the protein ingredient in processing of animal feeds. The main inputs in the fishmeal industry are low-quality grade omena and Nile perch by-products (mainly fish frames after fillet removal). In this way the fish subsector plays a significant forward linkage role in providing inputs to the animal feeds industry, especially the beef, dairy, and poultry sub-sectors.

\section{Regulatory Framework of Fish Processors in Kenya}

Fishery resources in Kenya are managed by the Department of Fisheries through the Fisheries

Act (Cap 378) and Maritime Act (Cap 250) of the Laws of Kenya, the Kenya Marine Fisheries Research Institute (KMFRI), established as a state corporation through the Science and Technology Act (Cap 250), undertakes fisheries research.

Other public institutions involved with fishery activities include regional development authorities under the Ministry of Regional Development, Ministry of Environment and Natural Resources, universities and public laboratories. The large-scale export-oriented private sector is organized under the Kenya Fish Processors and Exporters Association (AFIPEK), which has facilitated industry self-regulation, marketing and interfacing with the Government. The small, medium and large scale fish traders in Kenya are considering the formation of an umbrella organization. This association shall have corporate membership, comprising of associations into which these traders belong, and is aimed at influencing Government policy, providing training services and facilities to accelerate efficient and sustainable trade. A major drawback is that most of the small scale traders are not organized into strong associations. Fishermen lack strong cooperatives or associations, but there are efforts by several organizations, including the newly launched Beach Management Units (BMUs) to organize this vital group. In addition to these private sector players, there are several civil society and non-governmental organizations (NGOs) working in fisheries, especially on socio-economic and conservation issues.

The Kenya fisheries sector has operated without a comprehensive fisheries policy since independence (ROK, 2005). Fisheries production and management measures were, from time to time however, mentioned in various policy documents. Key among these include the various national Development Plans in which the government emphasized fish production from natural waters; National Food Policy (1981 and 1994) in which the importance of fish as a nutritious food commodity was emphasized; District Focus for Rural Development policy (1995) that required all districts to have fisheries presence irrespective of their fisheries potential; Poverty Reduction Strategy Paper (PRSP) of 2001 that introduced a social responsibility and poverty reduction element into the fisheries agenda; Economic Recovery Strategy for Wealth and Employment Creation 2003-2007 (ERS), into which the PRSP evolved, and that recognizes the contribution made by fisheries to local incomes, subsistence and nutrition. (ROK, 2005).

The fisheries policy is anchored in two recent sectoral strategies (ROK, 2005). The first is the strategy for the Ministry of Livestock and Fisheries Development (MoLFD) whose mission is "to create a favorable legal and regulatory framework for the sustainable development of the sub-sectors" including a favorable environment for the creation of a semi-autonomous fisheries institution under the ministry. The other sectoral strategy is the Strategy for Revitalizing Agriculture (SRA) 2004-2014 which recognizes the importance of fisheries. The lack of a comprehensive national fisheries policy has reduced management and research 
effectiveness, discouraged investment in the sector, and thus constrained production growth. The government has developed these polices to encourage value addition, marketing and fair trade in Kenya's fishery products worldwide.

In summary, various writers have supported the need to develop elaborate policy and regulatory frameworks in order to grow economic sectors. This view is supported by Namusonge (1999) and Mwirigi, Mukulu \& Karanja (2011).

Culture

According to the Oxford Dictionary, culture can be defined as the ideas, customs, and social behavior of a particular people or society. Value chain actors, especially upstream in the value chain, are characterized by low financial literacy levels and largely operate outside of the formal finance system. The lack of a savings culture is probably the single-most important constraint to growth of the fish value chain.

Historically, the fishing communities have shown little interest in saving because of the perception that there is always fish to catch if they need money. Furthermore, the fishermen typically spend a large part of their earnings on alcohol and prostitutes, both of which are in ample supply on the beaches. As a result, HIV/AIDS is wide-spread in the communities along the shores of Lake Victoria, destroying households and creating the most vulnerable and poorest sub-populations in Kenya (Ardjosoediro \& Neven, 2006).

Presentation style appeals and attracts the consumers especially for the fish and fishery products. Fish and its nature of fresh produce odour and its perishability makes consumers keep away from the products. A good packaging material improves the handling and shelf life of the products. Clean cut ready to cook or eat fishery products attracts more consumers than the raw whole fish. Food habits and food culture have direct impacts on the consumer preferences.

\section{Conclusion}

This value chain analysis of the developing countries fisheries sub-sector illustrates that a myopic focus on particular upgrading activities is unlikely to lead to growth. Strengthening the weak financial structure, reducing power imbalances in the governance structures, and resolving socio-cultural and environmental concerns have to take place concurrently. For example, the high levels of post-catch losses indicate that the introduction of coolers and improved ice distribution systems would be an upgrade strategy that could stimulate value chain growth. While this could indeed lead to higher profitability at first, without retaining these profits and reinvesting them back in to their business, value chain actors will not be able to grow their business. In addition to a dearth of accessible finance services, exploitative governance mechanisms, and limited business management skills, socio-cultural aspects of the fishing communities favoring consumption over savings stand in the way of business growth through reinvestment.

Even if the savings rate of fisher folk, artisanal fish processors and fishmongers improves and they reinvest in their business, growth will be severely hampered if environmental aspects are not taken into account. For example, more boats and more nets could lead to accelerated over-fishing in the shallow waters and a reduction of the overall fish stock. This risk needs to be addressed through a systemic enforcement of environmental protection measures and a diversification strategy that will direct some profits to other highpotential economic activities such as aquaculture or irrigated horticulture.

The value chain frame work has been used as powerful analysis tool for organizational strategic planning for nearly two decades now. The value chain frame work shows that the value chain of a company may be useful in identifying and understanding crucial aspects to achieve competitive strengths and core competencies in the market place. The model also reveals how the value chain activities are tied together to ultimately create value for the consumer.

This paper makes the following recommendations:

\section{Recommendations}

1. Value addition within the seafood value chain should be given priority in government planning. Private investors should be encouraged to invest in seafood value addition. The government can do this by, for instance, zero-rating imported value addition machinery.

2. Sea food farmers need to be equipped with the skills and knowledge that's they need to function at various stages of the value chain. Training initiatives would be important in this regard.

3. There is need for governments in developing economies to mainstream the seafood sector in its planning and in the process enhance regulation of the seafood sector to harness the benefits of formal operations. They could begin by encouraging the establishment of more fishing cooperatives in the coast, giving them clear and beneficial operational guidelines and facilitating them in the areas of value addition and marketing. 
4. There is need to continuously study and if necessary redefine the chain in order to rid it of unnecessary bottlenecks and operational challenges. This is because there exists numerous bottlenecks that slow down operations within the chain hence increasing the overall costs of the chain.

5. Market development is critical to the growth and development of the chain. It is necessary that new and diverse markets be opened up urgently in various part of the world to grow the sector and avail more benefits to the operators in the chain.

6. Information centers should be established to furnish various operators at various chain nodes with necessary information for purposes of planning investment decision making.

7. Inter-sector relationships need to be developed and nurtured. For instance, there exist a lot of relationships between seafood farming and tourism. These relationships would help to tap into the synergies that exist.

\section{References}

[1]. Ardjosoediro I. and Neven D. 2008. The Kenya capture fisheries value chain: An AMAP-FSKG value chain finance case study. USA: United States Agency for International Development (USAID).

[2]. Barney, J. 1991. Firm Resources and Sustained Competitive Advantage. Journal of Management, (March), 23 (2): 99-120.

[3]. Bracker, J., Keats, B., \& Pearson, J. 1988. Planning and Financial Performance among Small Firms in a Growth Industry, Strategic Management Journal (Nov/Dec), 22 (1):59-60

[4]. Bracker, J. \& Pearson, J. 1986. Planning and Financial Performance of Small Mature Firms. Strategic Management Journal, November-December, 503-522.

[5]. FAO (2012). Kenya Fishery country profile.

[6]. FAO (2006). Kenya Fishery country profile.

[7]. Jallow, A.M. 1995. Contribution of Improved Chokor Oven to Artisanal Fish smoking in The Gambia: In Workshop on Seeking Improvements in fish Technology in West Africa. IDAF Technical Report, No. 66

[8]. Lerner, M., \& Almor, T. (2002). Relationships among strategic capabilities nd the performance of women-owned small ventures, Journal of Small Business Management, 40(2): 09-125.

[9]. Mwirigi F.M, Mukulu, E. \& Karanja, K. 2011. Growing sound supply chain relationships among small firms: Lessons from Kenya. Journal of Human Resource and Entrepreneurship Development, Vol.3, No. 1, pp 63-71

[10]. Mintzberg, H. (1978). Patterns in strategy formation. Management Science, 24 (9), 934-948.

[11]. Namusonge, G.S. 1999. Entrepreneurship development Micro and small enterprises in Kenya. Agency for improving the policy environment in Mullei, A., \& Bokea, C. Nairobi: ICEG \& USAID.

[12]. Republic of Kenya (2005) .Annual Report 2005, Ministry of Livestock and Fisheries Development, Fisheries Department

[13]. Republic of Kenya 2005. Kenya Fisheries Policy. Kenya: Ministry of livestock and fisheries development.

[14]. Republic of Kenya (2008). Annual Report 2008, Ministry of Livestock and Fisheries Development, Fisheries Department

[15]. Robinson,R., \& Pearce, J. (1984). Research thrusts in small firm strategic planning. Academy of management review, 9 (1), 128137.

[16]. Schwenk, C. \& Shrader, C. 1993. Effects of formal strategic planning on financial performance in small firms: A met-analysis. Entrepreneurship Theory and Practice, Spring,3 (4): 53-64. 